\title{
Surgical treatment of symptomatic vertebral haemangiomas
}

\section{Leczenie chirurgiczne objawowych naczyniaków kręgosłupa}

\author{
Roman Jankowski', Stanisław Nowak', Ryszard Żukiel', Janusz Szymaś2, Bartosz Sokół' \\ IKatedra i Klinika Neurochirurgii i Neurotraumatologii, Uniwersytet Medyczny im. Karola Marcinkowskiego w Poznaniu \\ 2Pracownia Patomorfologii Neurochirurgicznej, Katedra Patomorfologii Klinicznej, Uniwersytet Medyczny im. Karola Marcinkowskiego w Poznaniu
}

Neurologia i Neurochirurgia Polska 2011; 45, 6: 577-582

\begin{abstract}
Background and purpose: Vertebral haemangiomas are relatively common, benign vascular lesions; symptomatic ones that cause spinal cord compression are rare, however. Only $0.9-1.2 \%$ of all vertebral haemangiomas are symptomatic. The aim of the paper is to present indications, operative techniques and stabilization methods in patients with symptomatic vertebral haemangiomas.

Material and methods: Clinical analysis included 7 patients treated between 1995 and 2007. There were 4 females and 3 males, aged 24 to 63 yrs (average age 44 yrs). Symptomatic vertebral haemangiomas were diagnosed on the basis of neuroradiological studies. Surgery was applied in all cases. Implantation of internal stabilization followed vertebral haemangioma resection.

Results: Localization of vertebral haemangiomas included 1 case in the cervical, 5 cases in the thoracic and 1 case in the lumbar segment of the vertebral column. Symptoms of medulla compression were observed in 7 patients. Neurological symptoms were caused usually by hypertrophy or ballooning of the posterior cortex of the vertebral body into the vertebral canal. The anterior surgical approach was carried out in 2 cases, posterolateral in 3 cases and posterior in 2 cases. Spinal stability was secured by various implant systems and autogenic bone grafts. Bone defects in the vertebral body were filled with acrylic cement in 4 patients. In histological examinations, cavernous types were found in all patients. Neurological condition improved after the treatment in 5 patients.
\end{abstract}

\section{Streszczenie}

Wstęp i cel pracy: Naczyniak kręgosłupa jest najczęstszym pierwotnym guzem kostnym kręgosłupa. Tylko 0,9-1,2\% naczyniaków powoduje neurologiczne objawy ubytkowe. W pracy przedstawiono wskazania, techniki operacyjne i sposoby stabilizacji u chorych leczonych z powodu objawowych naczyniaków kręgosłupa.

Materiał i metody: Analizą kliniczną objęto 7 chorych leczonych w latach 1995-2007, w tym 4 kobiety i 3 mężczyzn w wieku od 24 do 63 lat (średnia wieku wynosiła 44 lata). Diagnostyka opierała się na badaniach neuroradiologicznych. Wszyscy chorzy byli leczeni chirurgicznie. Po usunięciu naczyniaka przeprowadzano stabilizację wewnętrzną kręgosłupa metalowymi implantami i autogennym przeszczepem kostnym. Ubytek w trzonie kręgu w 4 przypadkach został wypełniony cementem akrylowym.

Wyniki: Naczyniaki kręgosłupa występowały najczęściej w odcinku piersiowym - 5 przypadków, w odcinkach szyjnym i lędźwiowym - po 1 przypadku. Objawy kliniczne ucisku rdzenia kręgowego stwierdzono u wszystkich chorych. Naczyniaki powodowały ucisk rdzenia kręgowego przez przerost i balonowate uwypuklenie zwykle tylnej ściany trzonu kręgowego. Przednie dojście operacyjne wykonano w 2 przypadkach, tylno-boczne w 3 przypadkach, a tylne w 2 przypadkach. W badaniu histologicznym u wszystkich chorych stwierdzono naczyniaki jamiste. Poprawę stanu neurologicznego obserwowano u 5 pacjentów.

Correspondence address: dr hab. Roman Jankowski, Katedra i Klinika Neurochirurgii i Neurotraumatologii, Uniwersytet Medyczny im. Karola Marcinkowskiego w Poznaniu, ul. Przybyszewskiego 49, 60-355 Poznań, e-mail: klinikanch@op.pl

Received: 19.04.2011; accepted: 20.06.2011 
Conclusions: No standard therapy exists for symptomatic thoracic vertebral haemangiomas. However, immediate surgical intervention is necessary in cases with acute compressive myelopathy before the symptoms become irreversible.

Key words: haemangioma, spine, surgery.

\section{Introduction}

Haemangiomas of the skeleton are most common in the spine; rarely they can be found in the calvaria of the skull or long bones such as the fibula, femur or humerus [1]. Haemangioma is a pathological lesion of hamartoma type that evolves from erroneous tissue fusions during embryogenesis [2]. Virchow described vertebral haemangioma in 1867 based on post-mortem examination [3]. Perman published the first radiological description of vertebral haemangioma in 1926 [3]. About 25.7\% of haemangiomas appear in the spine (in $64 \%$ as a solitary lesion and as multiple ones in $34 \%$ ). Haemangiomas constitute $2-3 \%$ of all spine tumours $[1,2,4]$. Clinical presentation relates to haemangiomas' classification into asymptomatic and symptomatic that exert spinal canal structures' compression $[2,5]$.

There are no established standards of care for patients with symptomatic spinal haemangiomas. The aim of this study is to present indications, operative techniques and stabilization methods in patients with symptomatic vertebral haemangiomas.

\section{Material and methods}

Symptomatic vertebral haemangiomas were found in 7 patients treated in the Department of Neurosurgery and Neurotraumatology in Poznań between 1995 and 2007. Our cohort consisted of 4 females and 3 males aged 24 to 63 years. The average age was 44 years. Most of the patients (4 cases) were in their third or sixth decade. The course of the disease was slowly progressive in 4 patients, in 2 of them the symptoms occurred suddenly while 1 patient had periods of aggravation and remission of the disease. Anamnesis in 5 patients was shorter than 6 months while in the other two it was longer and exceeded half a year. One woman presented with haemangioma symptoms in the $37^{\text {th }}$ week of her pregnancy.

The most characteristic sign was local spinal pain (7 cases). Four patients reported radicular pain. On admission to the Department, neurological examination
Wnioski: Nie ma ustalonych standardów leczenia u chorych z objawowymi naczyniakami kręgosłupa. Interwencja chirurgiczna polegająca na uwolnieniu rdzenia kręgowego z ucisku jest konieczna w przypadkach narastających neurologicznych objawów ubytkowych.

Słowa kluczowe: naczyniak, kręgosłup, leczenie operacyjne.

revealed complete transverse spinal injury in 2 patients. Partial transverse spinal injury symptoms were present in 5 patients.

Plain X-rays revealed thickening of the vertical bone beams in the vertebrae in all of the patients. Magnetic resonance (MR) of the spine disclosed increased intensity of the signal in T1- and T2-weighted images in all haemangiomas. Magnetic resonance imaging also revealed spinal cord compression that had resulted from hypertrophy and ballooning of the haemangioma into the spinal canal. Ischaemic signs that manifested as signal intensity changes in the spinal cord were present in three cases. Computed tomography (CT) images in the axial projections disclosed typical representation of dotted bony structure of the vertebrae that arise from the presence of thickened bony beams. Magnetic resonance and CT imaging studies allowed the initial clinical diagnosis.

Haemangiomas' localizations within the spine segments were as follows: thoracic spine -5 cases, cervical spine 1 case, lumbar spine - 1 case. One patient presented with haemangiomas in three vertebrae (Fig. 1A-C). Neuroradiological examination provided detailed localization of the haemangioma within vertebrae. The presence of haemangioma confined within the vertebral body alone was found in 2 cases; in 1 patient it occupied posterior parts of the vertebrae. Haemangiomas in the remaining four patients were located within the body as well as posterior parts of the vertebrae.

\section{Results}

Surgical approach was selected based on localization, the extent of the haemangioma within the vertebrae and the degree and localization of the nervous structures' compression within the spinal canal. The posterior approach (laminectomy) was elected in 2 cases. Anterior vertebrectomy in the cervical spine was performed in one case and vertebrectomy in the thoracic spine via thoracotomy was performed in one more case. The remaining 3 patients underwent surgery via the posterolateral approach - trans pedicular in 2 cases and costotransversectomy in 1 case. 

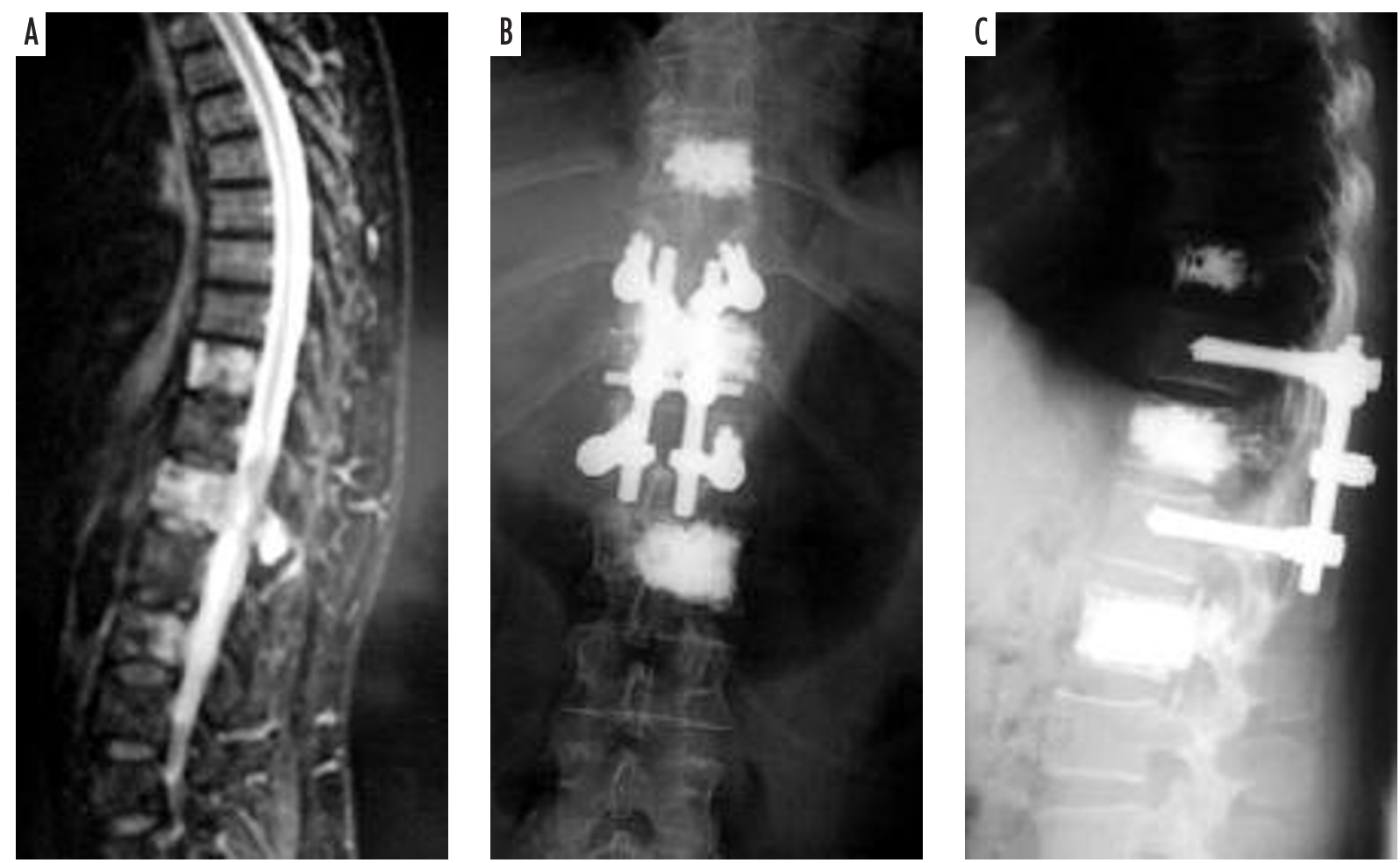

Fig. 1. A 67-year-old female with multiple vertebral haemangiomas who complained of intervertebral neuralgia and paraparesis of lower extremities. Neurological examination revealed conus medullaris injury syndrome. Magnetic resonance imaging examination disclosed vertebral haemangiomas in Th10, Th12 and L2 vertebrae. The Th12 haemangioma was responsible for spinal cord compression (A). Posterolateral approach was selected for surgery. Postoperative X-rays in anteroposterior (B) and lateral (C) projections show postoperative status after Thl2 haemangioma removal and transpedicular fusion. Bony deficit of the vertebrae was filled with acrylic cement. Th10 and L2 haemangiomas were treated via percutaneous vertebroplasty. Paraparesis and pain subsided after treatment

Spinal instrumentation was performed following haemangioma dissection (radical in 4 cases and partial in 3 cases). Transpedicular stabilization was performed in 4 cases. One patient had a vertebral body prosthesis implanted. In the remaining 2 patients spinal fixation was achieved with autogenous iliac bone grafts. Acrylic bone cement was used to fill vertebral body deficits in $4 \mathrm{pa}-$ tients. Surgery time varied from 240 to 360 minutes (average time 298 minutes). Blood transfusion was necessary in 5 patients. Blood loss varied from 300 to $2000 \mathrm{ml}$ (average loss $1014 \mathrm{ml}$ ).

Histological examination of surgical specimens revealed cavernous haemangiomas in all of the cases. Microscopically, within enlarged medullary cavities ca vernous vascular spaces filled with morphotic blood elements were present. Enlarged, thin-walled vascular spaces, varied in size, are usually lined up with flattened vascular endothelium. Reactive bony beams of various size and shape were often present on the margins (Fig. 2).

In our group we noticed no intra- or postoperative complications. Neurological improvement in the early

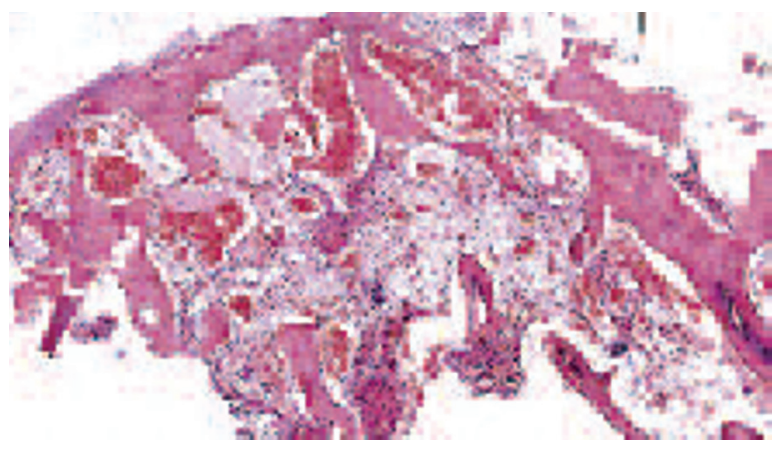

Fig. 2. Cavernous hemangioma of Th12 vertebrae. Large dilated vessels with thin walls expand marrow spaces. Endothelial-lined cavernous spaces are filled with blood. H\&E stain, $25 \times$

postoperative period was seen in 5 patients. In-hospital stay varied from 9 to 16 days (average 12 days).

Postoperative follow-up varied from 3 to 16 years in 6 patients. One patient did not follow the ordered follow-up schedule. In three patients radiotherapy followed partial haemangioma resection. Four patients presented with full remission of neurological deficits; one patient achieved partial recovery. In one case no changes 
in neurological status were present. Control X-rays proved satisfactory stability of the spine. Magnetic resonance ( 3 cases) and CT (1 case) examinations proved radical or partial haemangioma dissection. None of the cases showed any signs of spinal cord compression.

\section{Discussion}

Haemangiomas are the most common primary osseous tumours of the spine. They are found in $10 \%$ of the population [6], more often in women. The female to male ratio is $2: 1$. They are usually diagnosed in the fourth or fifth decade of life [7-9]. In our cohort the average age was 44 years, and women were in the majority.

Between 0.9 and $1.2 \%$ of spinal haemangiomas result in pain and neurological deficits $[10,11]$. Radicular and spinal signs result from haemangioma expansion into the spinal canal and intervertebral foramina rather than compressive fracture of the vertebrae. Multiple haemangiomas constitute $1 / 3$ of all haemangiomas [12,13] . Fifty-four percent of symptomatic spinal haemangiomas manifest with pain, the others with various types of neurological deficits [14]. All our patients presented with pain and neurological deficits. So-called "aggressive" haemangiomas result in rapidly progressive spinal cord compression syndrome [2]. The time interval between onset of pain and appearance of neurological deficits is short and averages one week [5]. We noted stroke-like course of the disease in two cases.

Despite the recent advances in diagnostics it is still not feasible to predict biological consequences of spinal haemangioma. Its course might resemble malignant spine tumour. In such cases, the destruction of the cortical layer of the vertebrae leads to expansion into the vertebral body, its arch and facets. Concomitantly, the development of pathological tissue leading to subperiosteal outgrowth into the subdural space (cortical layer's hypertrophy) results in spinal cord compression. Pathological fractures of the vertebral body are extremely rare $[4,12]$.

Neurological deficits might also result from acute epidural bleeding, circulatory disturbances (clotting, pathological vessels recanalization), haemangioma stroma's volume reduction or spinal cord ischaemia $[2,6,12$, $14,15]$.

Pregnancy is one of the risk factors that might reveal or aggravate the symptoms of haemangioma $[6,15,16]$. One of our patients presented with haemangioma symptoms in the $37^{\text {th }}$ week of pregnancy.
Haemangiomas are usually located in the thoracic spine $(60 \%)$, less often in the other segments - lumbar (29\%), cervical (6\%) and the sacrum (5\%). They are typically positioned within the vertebral body; still posterior parts of the vertebrae are occupied in 10 to $15 \%$ of cases $[12,13]$. In our group, haemangiomas were located mostly in the thoracic spine. Coexistence of lesions in the body and posterior elements of the vertebrae were found in 4 cases.

Plain X-rays of the spine remain the main diagnostic examination that reveals spinal haemangiomas. Thickened, vertical bony beams manifest as linear, parallel condensations that resemble "prison bars". Haemangiomas might also be visualized as osteolytic lesions that, along with the trabeculations, resemble "honey comb". Axial, spinal CT scans disclose a typical, "dotted" image of the vertebrae due to the presence of thickened bony beams. CT scans facilitate precise localization of a haemangioma within vertebral structures. Selective CT angiography enables circulation assessment within the haemangioma. MRI visualizes the extent of the haemangioma. Spinal haemangiomas prompt increased intensity of the signal in T1- and T2-weighted MR images. Paramagnetic contrast injections result in stronger contrast enhancement of the haemangioma's part that is located in the epidural space when compared to the part located within the vertebral body's bony structures $[4,6,12,13,17]$.

Due to low risk of haemangioma progression in asymptomatic patients, an incidentally found haemangioma does not require any treatment. Likewise, patients with local spinal pain should undergo annual radiological and neurological examination in order to detect progression. Rapid neurological progression of the symptoms necessitates treatment that might include irradiation, pathological vessels' obliteration and endovascular haemangioma elimination from circulation, radiotherapy, percutaneous vertebroplasty or obliteration (absolute alcohol) and surgical treatment - spinal canal decompression and stabilization $[12,14,16,18-20]$.

Endovascular embolisation rarely constitutes a sole therapeutic modality but reduces intraoperative blood loss when implemented prior to surgery. Favourable outcomes are also reported when pathological vessels overflowed with blood cause spinal cord compression. Foam filled with polyvinyl alcohol is used for pathological vessels' obliteration. Embolisation leads to immediate yet temporary remission of haemangioma symptoms. Failures of endovascular treatment modalities of vertebral haemangiomas are caused by the presence of tortuous feeders or by obliteration of capillar- 
ies that are essential for spinal cord and roots vascularisation $[20,21]$.

Literature analysis provides data suggesting the efficacy of radiotherapy of vertebral haemangioma but optimal dose, fractionation protocol and time period necessary for a therapeutic effect are controversial [22]. Radiotherapy targets vascular endothelium. An anti-inflammatory effect of $\mathrm{X}$-rays is also suggested. Bone remineralization is rarely found after radiotherapy [23-25]. Radiotherapy is implemented as a sole therapeutic modality in cases with contraindications for surgery or other therapeutic protocols. In general, radiotherapy is reserved for partially resected haemangiomas [25].

Heyd et al. [25] presented retrospective analysis of 84 patients irradiated for symptomatic vertebral haemangiomas between 1969 and 2008, the largest published so far. They collected data from seven centres in Germany; the follow-up period reached 39 years. The primary indication for radiotherapy was pain (97.6\% of cases). Other, coexisting neurological symptoms were present in $28.6 \%$ of cases. The median of total and single doses of radiation was $34 \mathrm{~Gy}$ and $2 \mathrm{~Gy}$, respectively. Total dose equal to or higher than $34 \mathrm{~Gy}$ was more efficient in comparison to doses lower than $34 \mathrm{~Gy}$. Median follow-up averaged 68 months. Complete remission of pain was observed in $69.1 \%$ of patients, partial in $28.6 \%$; in $9.5 \%$ of cases pain was persistent. Long-term follow-up revealed reossification of irradiated vertebrae in $26.2 \%$ of patients; no correlation with pain demission was shown. Occasionally, radiotoxicity-related complications occurred [25]. The aforementioned study proved high efficacy of radiotherapy, but it has limitations due to its retrospective nature and very long follow-up period. Various irradiation schemes were used within this period.

Percutaneous vertebroplasty, usually with polymethylmethacrylate (PMMA), is a relatively new, palliative technique of treatment of symptomatic haemangiomas. Patients with pathological fractures of the vertebral body and persistent pain are qualified for percutaneous vertebroplasty or kyphoplasty. Vertebroplasty is contra indicated in patients with haemangioma expansion into the spinal canal [11,26-29].

Sudden onset of neurological deficits qualifies the patient for imminent surgery. Various approaches and surgical techniques are implemented in the treatment of vertebral haemangiomas.

Laminectomy provides an unsatisfactory outcome. Removal of the posterior osteoligamentous complex without internal stabilization results in progressive kyphosis, pain aggravation and neurological deficits. Laminecto- my enables adequate decompression of spinal canal structures in cases with laminar or epidural haemangioma localization. Accordingly, laminectomy might be an elective, decompressive surgery. These cases, after temporary neurological recovery, subsequently deteriorate, necessitating vertebrectomy and stabilization in the second stage of the surgical treatment $[2,14,20,30]$.

Vertebral body haemangiomas require anterior approaches: cervical, thoracotomy, retroperitoneal or transperitoneal. In cases where both anterior and posterior elements of the vertebrae are destroyed by haemangioma, a two-stage procedure (posterior and anterior approach) is advocated [14,20,31-33]. Sometimes a bilateral, po sterolateral approach (transpedicular, costotransversectomy) that facilitates complete haemangioma resection and spinal cord decompression is feasible [34]. We implemented this approach in three of our patients.

Subsequent to haemangioma dissection and spinal cord decompression, spinal stabilization is necessary. For this purpose, metal implants are used. Bony deficits within vertebrae might be filled with acrylic cement [34]. We used acrylic cement in 4 of our patients.

Due to blood loss during surgery blood transfusions were necessary [31].

Histologically, haemangioma consists of vascular spaces lined with endothelial cells. In between vascular structures, fat, smooth muscle, connective tissue, bony structures, hemosiderin deposits and blood clots can be found. Haemangioma might be capillary, cavernous or mixed. Enlarged vessels form grape-like structures between vertebral bony structures in cavernous haemangiomas. Thin-walled blood vessels separated by a normal bone are found in capillary haemangiomas. Blood supply is much more robust in cavernous haemangiomas. Cavernous haemangiomas are more common $[1,4,12]$. We found only cavernous haemangiomas in our cohort.

Post-surgical radiotherapy is advocated in order to avoid recurrences that are reported in up to $90 \%$ of cases during three-year follow-up [19]. Three out of seven patients in our group who underwent partial resection were irradiated. We found no recurrences of haemangioma in any of them.

\section{Conclusions}

1. There are no established treatment protocols for patients with symptomatic vertebral haemangiomas.

2. In cases with progressive neurological deficits, surgical treatment that enables spinal cord decompression is necessary. 


\section{Disclosure}

Authors report no conflict of interest.

\section{References}

1. Fletcher Ch.D.M., Unni K.K., Mertens F. Pathology and genetics of tumours of soft tissue and bone. World Health Organization classification of tumours. IARC Press, Lyon 2002.

2. Harrison M.J., Eisenberg M.B., Ullman J.S., et al. Symptomatic cavernous malformations affecting the spine and spinal cord. Neurosurgery 1995; 37: 195-204.

3. Murphey M.D., Fairbairn K.J., Parman L.M., et al. From the archives of the AFIP. Musculoskeletal angiomatous lesions: radiologic-pathologic correlation. Radiographics 1995; 15: 893-917.

4. Koh J.S., Chang U.K., Haddix T. Cystes and other benign lesions. In: Kim D.H., Chang U.K., Kim S.H., Bilsky M.H. [eds.]. Tumors of the spine. Saunders Elservier, Philadelphia 2008; pp. 3-14.

5. Rachinger J., Buslei R., Engelhorn T., et al. Intradural-extramedullary cavernous hemangioma of the left motor root $\mathrm{C} 7-$ case report and update of the literature. Zentralbl Neurochir 2006; 67: 144-148.

6. Chi J.H., Manley G.T., Chou D. Pregnancy-related vertebral hemangioma, Case report, review of the literature, and management algorithm. Neurosurg Focus 2005; 19: E7.

7. Benny B.V., Nagpal A.S., Singh P., et al. Vascular causes of radiculopathy: a literature review. Spine J 2011; 11: 73-85.

8. Jha B., Choudhary A.K. Unusual cause of back pain in an adolescent patient: a case report and natural history of aggressive vertebral hemangioma in children. Pain Physician 2008; 11: 687-692.

9. Krueger E.G., Sobel G.L., Weinstein C. Vertebral hemangioma with compression of spinal cord. J Neurosurg 1961; 18: 331-338.

10. Healy M., Herz D.A., Pearl L. Spinal hemangiomas. Neurosurgery 1983; 13: 689-691.

11. Brunot S., Berge J., Barreau X., et al. Long term follow up of vertebral hemangiomas treated by percutaneous vertebroplasty. $J$ Radiol 2006; 86: 41-47.

12. Pastushyn A.I., Slin'ko E.I., Gyulnara M., et al. Vertebral hemangiomas: diagnosis, management, natural history and clinicopathological correlates in 86 patients. Surg Neurol 1998; 50: 535-547.

13. Rudnick J., Stern M. Symptomatic thoracic vertebral hemangioma. A case report and literature review. Arch Phys Med Rehabil 2004; 85: 1544-1547.

14. Fox M.W., Onofrio B.M. The natural history and management of symptomatic and asymptomatic vertebral hemangiomas. J Neurosurg 1993; 71: 36-45.

15. Tekkok I.H., Acikgoz B., Saglam S. Vertebral hemangioma symptomatic during pregnancy. Report of a case and review of the literature. Neurosurgery 1993; 32: 302-326.

16. Kiroglu Y., Benek B., Yagci B., et al. Spinal cord compression caused by vertebral hemangioma being symptomatic during pregnancy. Surg Neurol 2009; 71: 487-492.

17. Freidman D.P. Symptomatic vertebral hemangiomas: MR findings. Am J Roentgenol 1996; 167: 359-364.
18. Trojanowski T., Kamiński S., Janczarek M., et al. Methylmethacrylate embolisation and stabilization of vertebral haemangioma. Zbl Neurochir 1998 (Suppl): 154.

19. Doppman J.L., Oldfield E.H., Heiss J.D. Symptomatic vertebral hemangiomas: treatment by means of direct intralesional injection of ethanol. Radiology 2000; 214: 341-348.

20. Acosta F.L. Jr., Dowd C.F, Chin C., et al. Current treatment strategies and outcomes in the management of symptomatic vertebral hemangiomas. Neurosurgery 2006; 58: 287-295.

21. Ng V.W., Clifton A., Moore A.J. Preoperative endovascular embolisation of a vertebral haemangioma. J Bone Joint Surg Br 1997; 79: 808-811.

22. Micke O., Rades D., Winkler C., et al. Radiotherapy is effective in the treatment of symptomatic vertebral hemangiomas (SVH): Long-term results of a multicenter study in Germany. Int J Radiat Oncol Biol Phys 2004; 60 (Suppl 1): S244-S245.

23. Faria S.L., Schlupp W.R., Chiminazzo H. Jr. Radiotherapy in the treatment of vertebral hemangiomas. Int J Radiat Oncol Biol Phys 1985; 11: 387-390.

24. Miszczyk L., Ficek K., Trela K., et al. The efficacy of radiotherapy for vertebral hemangiomas. Neoplasma 2001; 48: 82-84.

25. Heyd R., Seegenschmiedt M.H., Rades D., et al. Radiotherapy for symptomatic vertebral hemangiomas: results of a multicenter study and literature review. Int J Radiation Oncology Biol Phys 2010; 77: 217-225.

26. Guglielmi G., Andreula C., Muto M., et al. Percutaneous vertebroplasty: indications, contraindications, technique, and complications. Acta Radiol 2005; 46: 256-268.

27. Deramond H., Depriester C., Galibert P., et al. Percutaneous vertebroplasty with polymethylmethacrylate. Technique, indications, and results. Radiol Clin North Am 1998; 36: 533-546.

28. Hadjipavlou A., Tosounidis T., Gaitanis I., et al. Balloon kyphoplasty as a single or as an adjunct procedure for the management of symptomatic vertebral haemangiomas. J Bone Joint Surg Br 2007; 89: 495-502.

29. Bas T., Aparisi F., Bas J.L. Efficacy and safety of ethanol injections in 18 cases of vertebral hemangioma: a mean follow-up of 2 years. Spine 2001; 26: 1577-1582.

30. Nguyen J.P., Djindjian M., Gaston A., et al. Vertebral hemangiomas presenting with neurologic symptoms. Surg Neurol 1987; 27: 391-397.

31. Templin C.R., Stambough J.B., Stambough J.L. Acute spinal cord compression caused by vertebral hemangioma. Spine J 2004; 4: 595-600.

32. Weinstein J.N. Surgical approach to spine tumors. Orthopedics 1989; 12: 897-905.

33. Boriani S., Weinstein J.N., Biagini R. Spine update: primary bone tumors of the spine: terminology and surgical staging. Spine 1997; 22: 1036-1044.

34. Castel E., Lazennec J.Y., Chiras J., et al. Acute spinal cord compression due to intraspinal bleeding from a vertebral hemangioma: two case reports. E Spine J 1999; 8: 224-248. 